\title{
Simulation of traffic flow in unsignalization intersection using computer software SIDRA in Baghdad city
}

\author{
Ali Mohammed ${ }^{1,2,{ }^{*}}$, Hassan Jony ${ }^{1}$, Alaa Shakir ${ }^{2}$, and Kamarudin Bin Ambak ${ }^{2}$ \\ ${ }^{1}$ University of Technology, Baghdad, Iraq \\ ${ }^{2}$ Faculty of Civil and Environmental Engineering Universiti Tun Hussein Onn Malaysia(UTHM), Parit Raja, Johor, Malaysia
}

\begin{abstract}
Computer simulation is a vital means for the examination of expressways and urban lanes and streets. Transportation experts concentrate on the arrangement and dissemination of traffic jams on roadways. The objective of this study is to calculate and analyses the travel time, delay time, degree of saturation, and level of service and travel speed in Jordan intersection in Baghdad, Iraq using Sidra software. The number of vehicles passing Jordan intersection was recorded by the author of this work from $7 \mathrm{am}$ to $3 \mathrm{pm}$ for four days. A simulation model has been used to assess the performance of the current intersection. Results demonstrated that the level of service (LOS) for Jordan intersection is D with (35 $\mathrm{sec} / \mathrm{veh})$ average delay and degree of saturation $(0.996 \mathrm{v} / \mathrm{c})$. It was concluded that Jordan intersection needs further developments like using intelligent transportation system application (ITS) to regulate traffic signals, whereby reducing traffic jam, using closed circuit TV (CCTV) might assist traffic office in identifying jam point to reduce traffic jam.
\end{abstract}

\section{Introduction}

Traffic jam happens when a volume of Traffic produces demand for more space as compared to the accessible street limit; this point is generally expressed as the degree of saturation. There are various particular circumstances that cause traffic jams; the vast majority of them decrease the limit of a street at a given point or over a specific length. Around half of U.S. traffic jam is repeating [2], and is ascribed to sheer weight of traffic; a major of the other half is attributed to the movement to traffic Ali used SIDRA software to assess the traffic flow in Roundabout and intersection in Bandar Baru Bangi [2], Al-Mimany, used Sidra to analyze and assess the traffic network in Kirkuk city [3]. Ibrahim investigated the assessment of Models for roundabout capacity and performance estimation for using SIDRA, ARCADY, RODEL, SYNCHRO models and Highway Capacity Manual model (HCM 2010) to carry out the analyses [4]. Examined the evaluation and enhancement of traffic operation for Al-Zeoat Intersection in AlRamadi city, using SIDRA traffic program [5]. investigated the urban street network in kut city, using geometrics techniques like (GPS, GIS) for detecting the traffic flow patterns of the selected network [6]. HCM (Highway Capacity Manual), HCS and SYNCHRO 6 computer program for operational analysis of WadiSaqra signalized intersection in Amman [7]. used aaSIDRA computer Software to Optimize the Traffic Flow in Bandar Baru Bangi Roundabout and intersection in Selangor, Malaysia [9].
The Jordan intersection in Baghdad city, which connects Al-Mansour quarter and Hay Al -Jameeah quarter could be described as the busiest intersection with the maximum traffic jams intersections in Baghdad connects the most vital areas in Baghdad nearby 14th Ramdhan intersection which is a commercial district having numerous shopping centers, governmental facilities like passports office, Iraqi citizenship office, and traffic office. Therefore, it encounters massive jams in the day. Besides, Jordan intersection is linked with Al-Nessor roundabout which is a congested area.

\section{Data collection}

Data has been collected from the field using a video camera with high storage capacity (80 GB) and a longlife battery (battery charging lasts for 10 hours). This camera has been installed on the alrashed bank building. a good vantage points for collecting data. The time of recording started from off-peak (7:00 AM) till another off-peak (3:00 PM) and was evaluated every 15 minutes during two periods the day which is (7am-12pm) and $(12 \mathrm{pm}-3 \mathrm{pm})$. Table1: shows the traffic volume data expressed by a number of cars for all direction, Table1 shows the input worksheet required for analysis of the existing geometric, traffic, and signalized conditions so this data was conducted over three days. Fig 1 and 2 shows the existing peak traffic flow determined by SIDRA computer program.

SIDRA computer software has been created by the 
Australian Road Research Board (ARRB), Transport Research Ltd., as a guide for outline and assessment of crossing points, for example, signalized convergences, roundabouts, two-way stop control, and caution sign control crossing points $[10,11,12]$. In assessing and comparing behavior of roundabouts, there are a few advantages that the SIDRA model has over some other programming model; it gives solid appraisals of geometric delays and related breakdown impacts for the different crossing point sorts. This property of the software is essential to the computation of new options for the intersection treatments consistently.

Table 1. Traffic Volume at Jordan Intersection for all Approaches each Quarter Hour.

\begin{tabular}{|c|c|c|c|c|c|c|c|c|c|c|}
\hline \multirow[t]{2}{*}{ Time } & \multicolumn{3}{|c|}{$\begin{array}{l}\text { From Street } \\
\text { Jordan Road }\end{array}$} & \multicolumn{3}{|c|}{$\begin{array}{l}\text { From } \\
\text { Yarmouk } \\
\text { Road }\end{array}$} & \multicolumn{3}{|c|}{$\begin{array}{l}\text { From } \\
\text { Baghdad } \\
\text { Tower Road }\end{array}$} & $\begin{array}{l}\text { To } \\
\text { tal }\end{array}$ \\
\hline & $\mathrm{L}$ & $\begin{array}{l}\mathrm{S} \\
\mathrm{T}\end{array}$ & $\mathrm{R}$ & $\mathrm{L}$ & $\begin{array}{l}\mathrm{S} \\
\mathrm{T}\end{array}$ & $\mathrm{R}$ & $\mathrm{L}$ & $\begin{array}{l}\mathrm{S} \\
\mathrm{T}\end{array}$ & $\begin{array}{l}\mathrm{U} \\
\mathrm{T} \\
\mathrm{U} \\
\mathrm{R} \\
\mathrm{N}\end{array}$ & \\
\hline $\begin{array}{c}7: 00- \\
7: 15 \\
\text { am }\end{array}$ & 30 & 33 & 35 & 41 & 33 & 38 & 29 & 50 & 65 & $\begin{array}{c}35 \\
4\end{array}$ \\
\hline $\begin{array}{l}7: 15- \\
7: 30\end{array}$ & $\begin{array}{c}11 \\
5\end{array}$ & 55 & 60 & 67 & 62 & 71 & 77 & 70 & 78 & $\begin{array}{c}65 \\
5\end{array}$ \\
\hline $7: 30-$ & 17 & 19 & 21 & 12 & 17 & 18 & 19 & 21 & 19 & 16 \\
\hline $7: 45$ & 9 & 6 & 1 & 2 & 8 & 3 & 7 & 1 & 8 & 75 \\
\hline $\begin{array}{l}7: 45- \\
8: 00\end{array}$ & $\begin{array}{c}28 \\
0\end{array}$ & $\begin{array}{c}37 \\
9\end{array}$ & 97 & $\begin{array}{c}25 \\
0\end{array}$ & $\begin{array}{c}25 \\
0\end{array}$ & $\begin{array}{c}25 \\
9\end{array}$ & $\begin{array}{c}24 \\
0\end{array}$ & $\begin{array}{c}26 \\
9\end{array}$ & $\begin{array}{c}32 \\
4\end{array}$ & $\begin{array}{l}23 \\
48\end{array}$ \\
\hline $8: 00-$ & 17 & 15 & 16 & 17 & 15 & 16 & 18 & 18 & 20 & 15 \\
\hline $8: 15$ & 8 & 4 & 5 & 0 & 4 & 9 & 7 & 7 & 3 & 67 \\
\hline $8: 15-$ & 10 & 12 & 17 & 13 & 15 & 13 & 13 & 15 & 10 & 11 \\
\hline $8: 30$ & 3 & 0 & 2 & 3 & 5 & 4 & 0 & 0 & 2 & 99 \\
\hline $\begin{array}{l}8: 30- \\
8: 45\end{array}$ & 64 & 77 & 73 & 65 & 68 & 69 & 72 & 77 & 71 & $\begin{array}{c}63 \\
6\end{array}$ \\
\hline $\begin{array}{l}8: 45- \\
9: 00\end{array}$ & 69 & 66 & 65 & 55 & 64 & 63 & 71 & 72 & 77 & $\begin{array}{c}60 \\
2\end{array}$ \\
\hline $\begin{array}{l}9: 00- \\
9: 15\end{array}$ & 62 & 60 & 69 & 72 & 72 & 71 & 68 & 55 & 59 & $\begin{array}{c}58 \\
8\end{array}$ \\
\hline $\begin{array}{l}9: 15- \\
9: 30\end{array}$ & 58 & 49 & 66 & 52 & 45 & 55 & 63 & 68 & 70 & $\begin{array}{c}52 \\
6\end{array}$ \\
\hline $\begin{array}{l}9: 30- \\
9: 45\end{array}$ & 55 & 34 & 51 & 58 & 42 & 52 & 58 & 55 & 79 & $\begin{array}{c}48 \\
4\end{array}$ \\
\hline $\begin{array}{l}9: 45- \\
10: 00\end{array}$ & 44 & 49 & 54 & 53 & 48 & 47 & 58 & 59 & 66 & $\begin{array}{c}47 \\
8\end{array}$ \\
\hline
\end{tabular}

\begin{tabular}{|c|c|c|c|c|c|c|c|c|c|c|}
\hline $\begin{array}{c}10: 00- \\
10: 15\end{array}$ & 49 & 66 & 77 & 69 & 73 & 66 & 68 & 65 & 62 & $\begin{array}{c}59 \\
5\end{array}$ \\
\hline $\begin{array}{c}10: 15- \\
1: 30\end{array}$ & 42 & 55 & 63 & 61 & 65 & 63 & 69 & 70 & 72 & $\begin{array}{c}56 \\
0\end{array}$ \\
\hline $\begin{array}{c}10: 30- \\
10: 45\end{array}$ & 45 & 44 & 59 & 67 & 72 & 67 & 65 & 59 & 60 & $\begin{array}{c}53 \\
8\end{array}$ \\
\hline $\begin{array}{c}10: 45- \\
11: 00\end{array}$ & 48 & 48 & 53 & 55 & 69 & 56 & 58 & 64 & 60 & 71 \\
\hline $\begin{array}{l}11: 00- \\
11: 15\end{array}$ & 44 & 44 & 32 & 44 & 59 & 66 & 70 & 79 & 75 & 74 \\
\hline $\begin{array}{l}11: 15- \\
11: 30\end{array}$ & 40 & 40 & 37 & 42 & 61 & 68 & 76 & 80 & 79 & 76 \\
\hline $\begin{array}{l}11: 30- \\
11: 45\end{array}$ & 47 & 47 & 41 & 52 & 58 & 61 & 74 & 79 & 81 & 79 \\
\hline $\begin{array}{c}11: 45- \\
12: 00 \\
\text { pm }\end{array}$ & 19 & 19 & 46 & 55 & 59 & 65 & 77 & 83 & 85 & 87 \\
\hline $\begin{array}{l}12: 00- \\
12: 15\end{array}$ & 39 & 39 & 50 & 54 & 61 & 68 & 79 & 86 & 86 & 75 \\
\hline $\begin{array}{l}12: 15- \\
12: 30\end{array}$ & 41 & 53 & 57 & 67 & 60 & 84 & 83 & 89 & 88 & $\begin{array}{c}62 \\
2\end{array}$ \\
\hline $\begin{array}{c}12: 30- \\
12: 45\end{array}$ & 55 & 57 & 60 & 70 & 68 & 80 & 83 & 86 & 83 & $\begin{array}{c}64 \\
2\end{array}$ \\
\hline $\begin{array}{l}12: 45- \\
01: 00\end{array}$ & 46 & 55 & 62 & 73 & 71 & 82 & 86 & 83 & 79 & $\begin{array}{c}63 \\
7\end{array}$ \\
\hline $\begin{array}{c}01: 00- \\
01: 15\end{array}$ & 49 & 60 & 69 & 70 & 74 & 78 & 88 & 90 & 93 & $\begin{array}{c}67 \\
1\end{array}$ \\
\hline $\begin{array}{c}01: 15- \\
01: 45\end{array}$ & 47 & 66 & 55 & 73 & 70 & 77 & 84 & 85 & 89 & $\begin{array}{c}64 \\
6\end{array}$ \\
\hline $\begin{array}{c}01: 45- \\
02: 00\end{array}$ & 49 & 66 & 55 & 73 & 70 & 79 & 83 & 85 & 85 & $\begin{array}{c}64 \\
5\end{array}$ \\
\hline $\begin{array}{c}02: 00- \\
02: 15\end{array}$ & 47 & 68 & 53 & 69 & 73 & 70 & 84 & 88 & 79 & $\begin{array}{c}63 \\
1\end{array}$ \\
\hline $\begin{array}{c}02: 15- \\
02: 30\end{array}$ & 45 & 70 & 55 & 74 & 70 & 73 & 83 & 85 & 89 & $\begin{array}{c}64 \\
4\end{array}$ \\
\hline $\begin{array}{c}02: 30- \\
02: 45\end{array}$ & 44 & 72 & 55 & 75 & 70 & 69 & 81 & 85 & 89 & $\begin{array}{c}64 \\
0\end{array}$ \\
\hline $\begin{array}{c}02: 45- \\
3: 00\end{array}$ & 89 & 87 & 98 & 77 & 88 & 71 & 79 & 86 & 94 & $\begin{array}{c}76 \\
9\end{array}$ \\
\hline
\end{tabular}




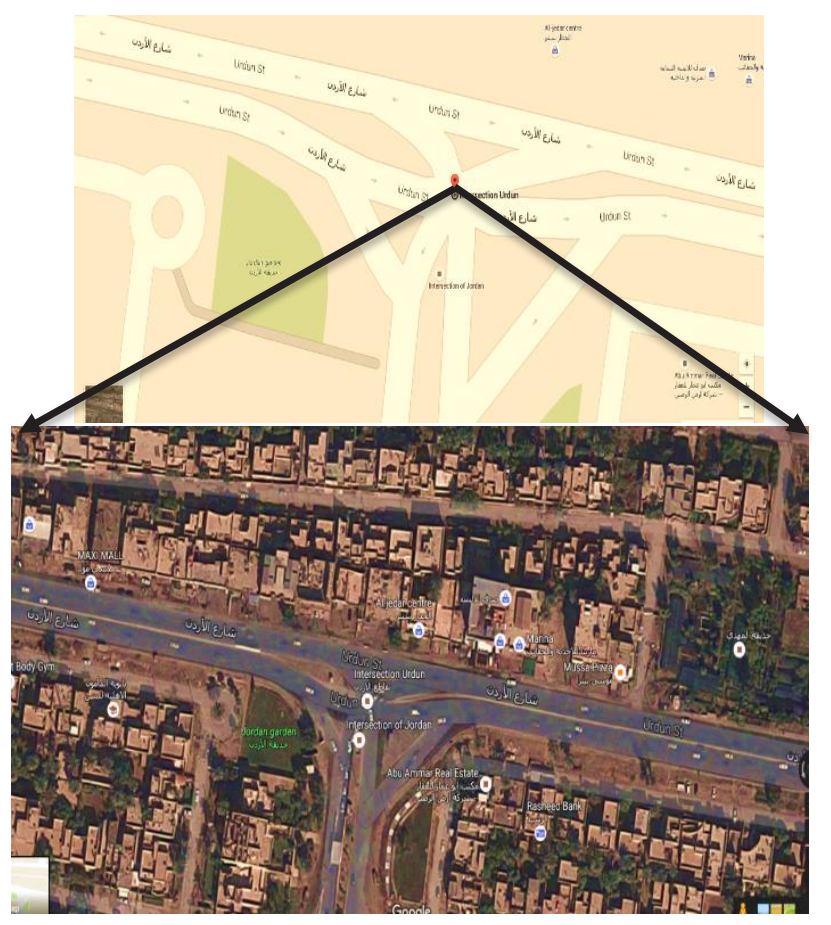

Fig. 1. Jordan intersection study area.

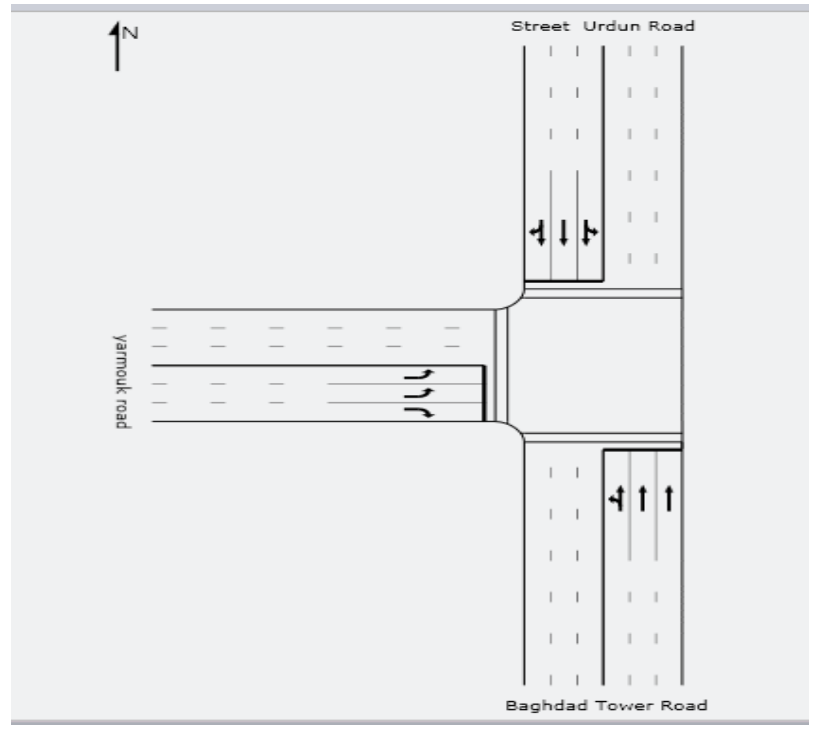

Fig.2. Existing Peak Traffic Flow as Shown by SIDRA

Table 2. Level of service definitions based on delay hem (for vehicles) [11]

\begin{tabular}{|c|c|c|}
\hline LOS & $\begin{array}{c}\text { Control Delay } \\
\text { (signalized) sec/veh }\end{array}$ & $\begin{array}{c}\text { Delay } \\
\text { sec/veh (unsignalized) }\end{array}$ \\
\hline $\mathrm{A}$ & $\leq 10 \mathrm{sec}$ & $\leq 10 \mathrm{sec}$ \\
\hline $\mathrm{B}$ & $10-20$ & $10-15$ \\
\hline $\mathrm{C}$ & $20-35$ & $15-25$ \\
\hline $\mathrm{D}$ & $35-55$ & $25-35$ \\
\hline $\mathrm{E}$ & $55-80$ & $35-50$ \\
\hline
\end{tabular}

\begin{tabular}{|c|c|c|}
\hline $\mathrm{F}$ & $>80$ & $>50$ \\
\hline
\end{tabular}

\section{Results and discussion}

\subsection{Peak hour volumes}

Traffic flow shown in Table 1was analyzed using excel program to identify the peak hour. The peak hour at Jordan intersection observed at 8:00 a.m. The total traffic volumes within this hour were recorded as $(4023 \mathrm{pc} / \mathrm{h})$ whereas the lease number of vehicles passing Jordan intersection were observed at10.00 am where the total traffic volumes at that hour were $(962 \mathrm{pc} / \mathrm{h})$ as shown Fig3. Total traffic flow percentage is illuminated in Fig.4 traffic flow percentage is evaluated by dividing the number of cars in each direction by the total number of cars. Total traffic flow from Yarmouk Street approach is $33 \%$, from Baghdad Tower is $37 \%$ and from Jordan intersection is $30 \%$.

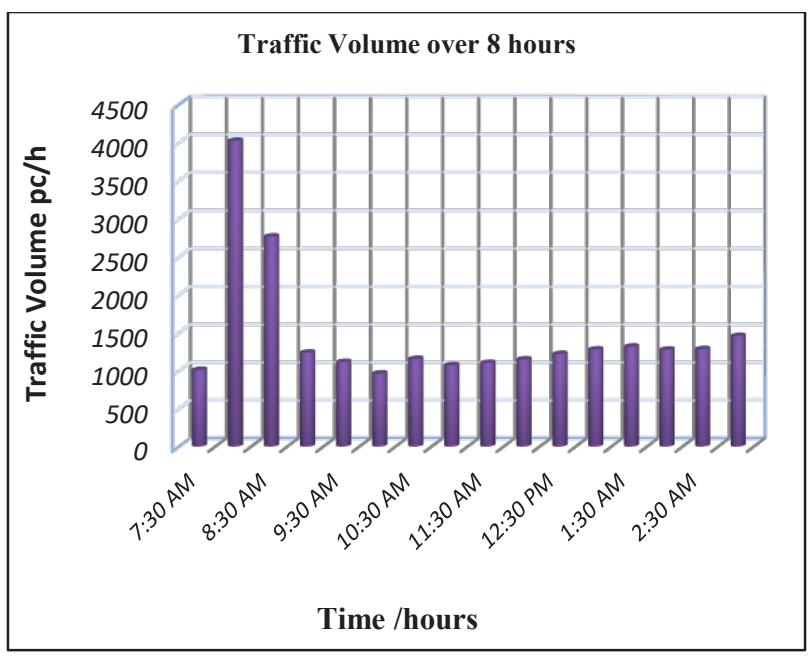

Fig.3. Total traffic volumes at Jordan intersection each one hour

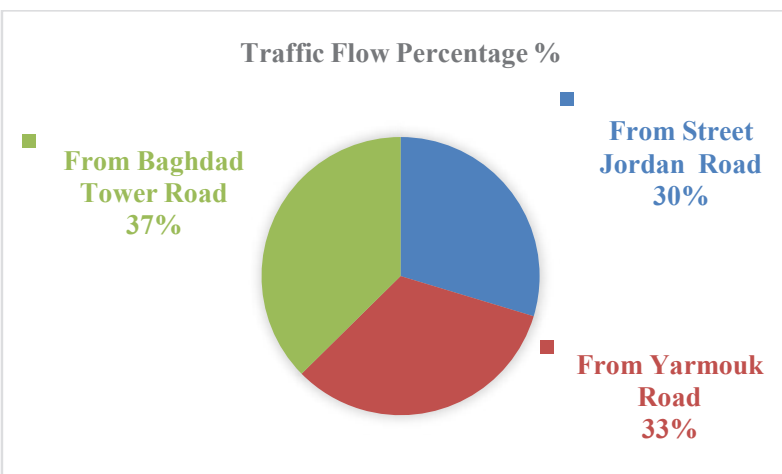

Fig.4. Total traffic flow Percentage at Jordan intersection 
Table 3. Traffic Volume At Jordan Intersection For All Approaches Each Half Hour

\begin{tabular}{|c|c|c|c|c|}
\hline Time & $\begin{array}{l}\text { From } \\
\text { Street } \\
\text { Jordan }\end{array}$ & $\begin{array}{l}\text { From } \\
\text { Yarmouk } \\
\text { Road }\end{array}$ & $\begin{array}{l}\text { From } \\
\text { Baghdad } \\
\text { Tower } \\
\text { Road }\end{array}$ & Total \\
\hline 07:30 am & 328 & 312 & 369 & 1009 \\
\hline 08:00 & 1342 & 1242 & 1439 & 4023 \\
\hline 08:30 & 892 & 915 & 959 & 2766 \\
\hline 09:00 & 414 & 384 & 440 & 1238 \\
\hline 09:30 & 364 & 367 & 383 & 1114 \\
\hline $10: 00$ & 287 & 300 & 375 & 962 \\
\hline $10: 30$ & 352 & 397 & 406 & 1155 \\
\hline $11: 00$ & 304 & 389 & 379 & 1072 \\
\hline $11: 30$ & 239 & 400 & 463 & 1102 \\
\hline $12: 00 \mathrm{pm}$ & 260 & 394 & 494 & 1148 \\
\hline $12: 30$ & 294 & 419 & 507 & 1220 \\
\hline 01:00 & 335 & 444 & 500 & 1279 \\
\hline 01:30 & 346 & 442 & 529 & 1317 \\
\hline 02:00 & 338 & 434 & 504 & 1276 \\
\hline $02: 30$ & 341 & 431 & 512 & 1284 \\
\hline 03:00 & 274 & 236 & 259 & 769 \\
\hline
\end{tabular}

The data was collected for each line for all the directions (left, right and through) and summed up during half an hour to recognize the number of cars passing the intersection during half an hour, the total number of cars passing Jordan intersection was 1,342 cars at 8:00 am whilst the total number of cars passing the intersection at 1:30 pm was recorded as 346 cars, while the number of cars passing al Yarmouk street was around 1,242 cars at 8:00 am, while the number of cars passing the same street was 444 cars at 1:30 pm. The number of cars passing Baghdad Tower at 8:00 am was 1,439 cars, whilst in 1:30 pm were recorded as 529 cars as shown in Table 3.

The percentage of cars passing the intersection each half an hour was calculated from Table 3 by dividing the total number of cars passing Yarmouk Street, Baghdad Tower and Jordan intersection during half an hour by the total number of cars shown in Table 3 to arrive at the percentage of cars passing

Table 4. Traffic percentage volume at Jordan intersection for all approaches for each in half an hour

\begin{tabular}{|c|c|c|c|c|}
\hline Time & $\begin{array}{l}\text { From } \\
\text { Street } \\
\text { Jordan }\end{array}$ & $\begin{array}{l}\text { From } \\
\text { Yarmouk } \\
\text { Road }\end{array}$ & $\begin{array}{l}\text { From } \\
\text { Baghdad } \\
\text { Tower Road }\end{array}$ & Total \\
\hline $07: 30 \mathrm{am}$ & $33 \%$ & $31 \%$ & $37 \%$ & $100 \%$ \\
\hline 08:00 & $33 \%$ & $31 \%$ & $36 \%$ & $100 \%$ \\
\hline $08: 30$ & $32 \%$ & $33 \%$ & $35 \%$ & $100 \%$ \\
\hline 09:00 & $33 \%$ & $31 \%$ & $36 \%$ & $100 \%$ \\
\hline $09: 30$ & $33 \%$ & $33 \%$ & $34 \%$ & $100 \%$ \\
\hline $10: 00$ & $30 \%$ & $31 \%$ & $39 \%$ & $100 \%$ \\
\hline $10: 30$ & $30 \%$ & $34 \%$ & $35 \%$ & $100 \%$ \\
\hline $11: 00$ & $28 \%$ & $36 \%$ & $35 \%$ & $100 \%$ \\
\hline $11: 30$ & $22 \%$ & $36 \%$ & $42 \%$ & $100 \%$ \\
\hline $12: 00 \mathrm{pm}$ & $23 \%$ & $34 \%$ & $43 \%$ & $100 \%$ \\
\hline $12: 30$ & $24 \%$ & $34 \%$ & $42 \%$ & $100 \%$ \\
\hline 01:00 & $26 \%$ & $35 \%$ & $39 \%$ & $100 \%$ \\
\hline $01: 30$ & $26 \%$ & $34 \%$ & $40 \%$ & $100 \%$ \\
\hline $02: 00$ & $26 \%$ & $34 \%$ & $39 \%$ & $100 \%$ \\
\hline $02: 30$ & $27 \%$ & $34 \%$ & $40 \%$ & $100 \%$ \\
\hline 03:00 & $36 \%$ & $33 \%$ & $39 \%$ & $100 \%$ \\
\hline Max & $34 \%$ & $36 \%$ & $43 \%$ & \\
\hline Mini & $22 \%$ & $31 \%$ & $34 \%$ & \\
\hline Average & $29 \%$ & $33 \%$ & $38 \%$ & \\
\hline
\end{tabular}

the intersection. It was demonstrated that the highest percentage was recorded from 7:30 am to 9:30 am with $33 \%$, while the percentage of cars passing Jordan Street were as high as $36 \%$ at 3:00 pm. However, the percentage at Yarmouk Street was significantly different as the highest percentage was recorded at 11:00 am with $36 \%$ and $35 \%$ at $1: 00 \mathrm{pm}$. The percentage of cars passing Baghdad Tower was $42 \%$ at $11: 30$ am and $40 \%$ 
at 1:30 pm and 2:30 pm as shown in Table 4. The percentage of vehicle passing the intersection each half hour for 8 hours is indicated in Fig. 5

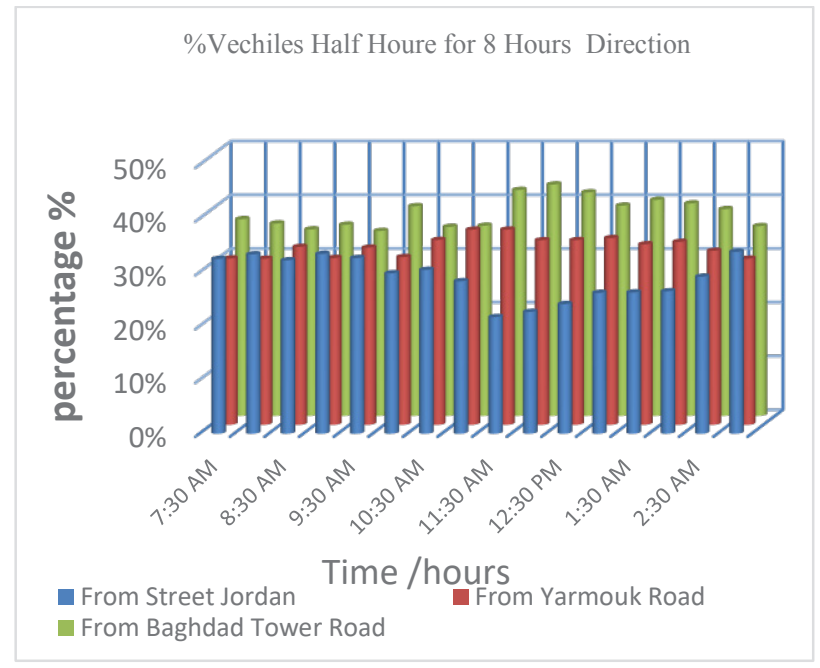

Fig.5. \%Vehicles per Half hours for 10 hours' direction

Table 5. PHF values for Jordan intersection approaches

\begin{tabular}{|c|c|c|}
\hline \multirow{2}{*}{ Approach } & Movement & PHF \\
\hline From Street Jordan Road & $\mathrm{L}$ & 0.2 \\
\cline { 2 - 3 } & $\mathrm{St}$ & 0.032 \\
\cline { 2 - 3 } & $\mathrm{R}$ & 0.3 \\
\hline From Yarmouk Road & $\mathrm{L}$ & 0.3 \\
\cline { 2 - 3 } & $\mathrm{St}$ & 0.3 \\
\cline { 2 - 3 } & $\mathrm{R}$ & 0.3 \\
\hline $\begin{array}{c}\text { From Baghdad Tower } \\
\text { Road }\end{array}$ & $\mathrm{L}$ & 0.4 \\
\cline { 2 - 3 } & $\mathrm{St}$ & 0.3 \\
\cline { 2 - 3 } & $\mathrm{U}$ turn & 0.3 \\
\hline
\end{tabular}

Peak Hour Factor (PHF) is the ratio between total volume and the maximum volume per $30 \mathrm{~min}$ rate of flow within the hour [Garber 2010]. Table 5 show PHF values for all approaches at both squares
Table 6. Results of the analysis by SIDRA

\begin{tabular}{|c|c|c|}
\hline Approach & $\begin{array}{c}\text { Average } \\
\text { Delay } \\
\text { sec/veh }\end{array}$ & LOS \\
\hline From Street Jordan Road & 36.0 & D \\
\hline From Yarmouk Road & 4.3 & A \\
\hline From Baghdad Tower Road & 61.6 & E \\
\hline
\end{tabular}

\subsection{Existing LOS at Jordan intersection}

Level of Service (LOS) Method is described based on the US Highway Capacity Manual (HCM) a subjective measure used to relate the efficiency of traffic flow. LOS is utilized to dissect highway by sorting traffic flow and doling out quality levels of movement in view of execution measure like speed, density [Highway Capacity Manual HCM, 2010]. LOS definitions based on delay HCM (for vehicles) is indicated in Table 6. Existing LOS was investigated in this study using Computer Simulation Sidra Software. Results illustrated that Jordan Street LOS is (A) while the Yarmouk Road LOS is (E). However, Baghdad Tower LOS of the intersection is (D) as shown in Fig.6, hence it is might be described as unstable flow. Speed is adversely correlated with traffic flow. Average delay is computed using SIDRA software and is related with LOS as given in Table 6

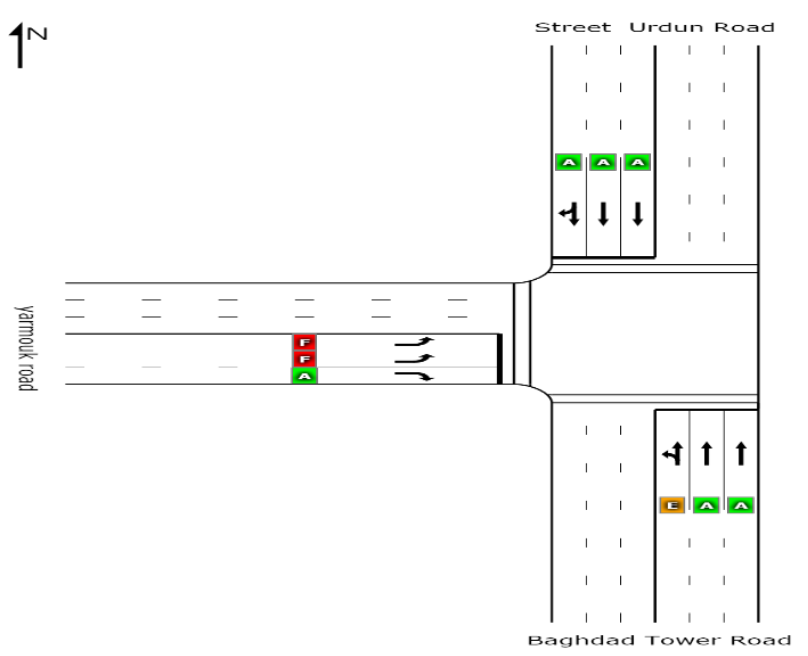




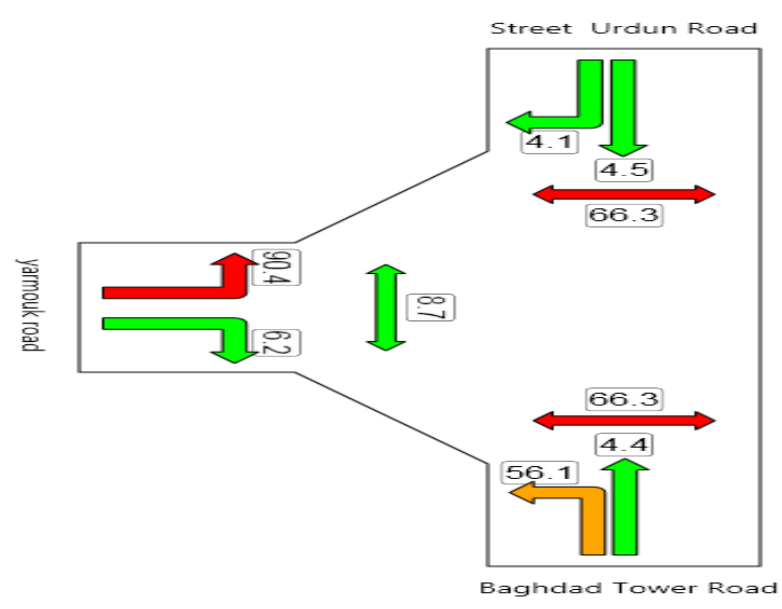

Fig.7. Details of LOS for Jordan intersection approaches

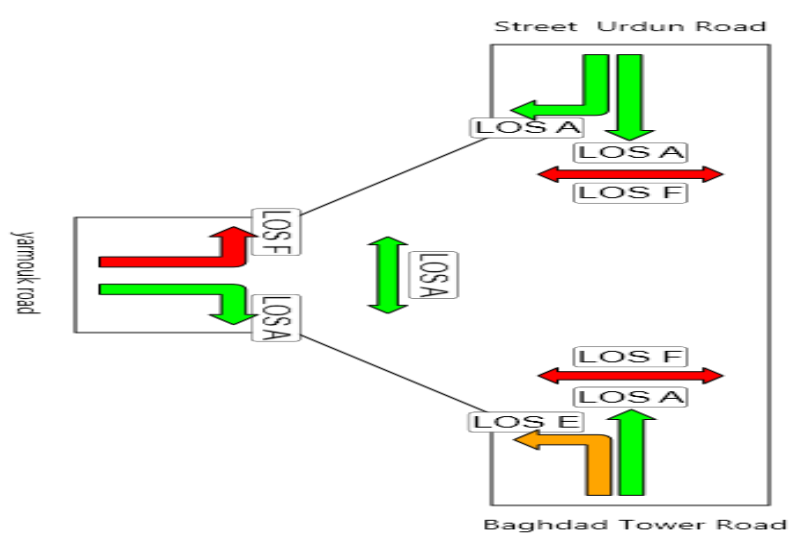

Fig.8. Results for average delay for Jordan intersection approaches

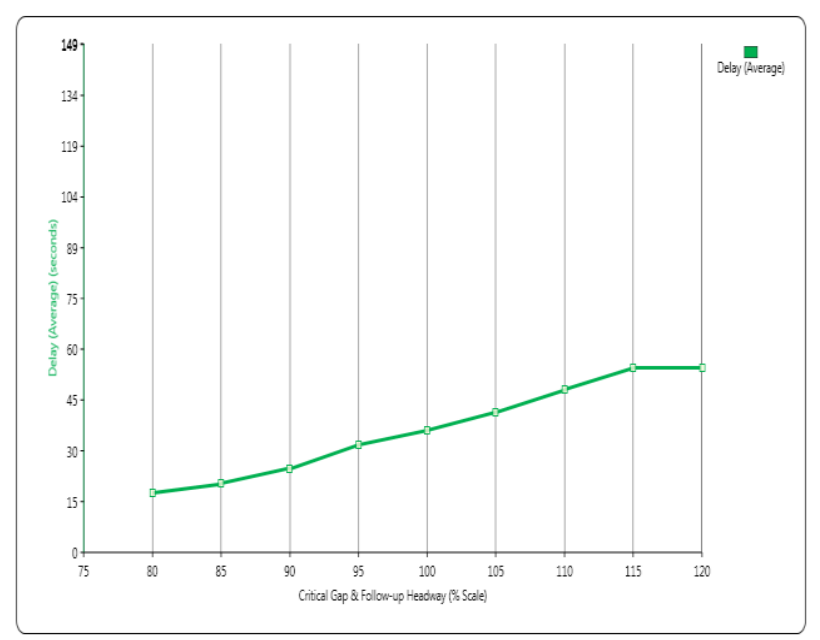

Fig.9. Relation between average delay and follow up headway

\subsection{Average delay}

The average delay is a crucial factor in forecasting travel time. Results for the delay is indicated in Fig. 8 which shows that both Jordan Street and Yarmouk Street have two colours red and green, red refers to LOS F and green refers to LOS A which has the minimum delay. Delay is adversely related to LOS when the delay is minimized LOS is enhanced [Turley, 2007]. Whilst, Baghdad Tower Road has two colours orange and green, green refers to LOS A and orange refers to LOS E. Relation between average delay and follow up headway is illustrated in Fig.9, It is obvious to note that the follow up heady increase with the increase of average delay. Total delay for Jordan intersection was recorded as 35.4 sec

\subsection{Degree of saturation}

The level of saturation (\%) is a proportion of demand to limit on each lane to deal with the intersection, with an estimation of $100 \%$ implying that demand and limit are equivalent and no further movement can advance through the intersection. Values more than $85 \%$ are normally viewed as torment from movement clog, with lines of vehicles starting to shape. according to colour code based on a degree of saturation. Each degree has a specific colour. Results for the degree of saturation is clarified in Fig.10. Green colour refers to less than 0.6 degrees of saturation, it was observed that Al Yarmouk Street has pink colour means that degree of saturation approach (0.8-0.9), whilst Baghdad Tower road has an orange colour, which refers to (0.9-1) degree of saturation. A relation between Degrees of Saturation and follow up headway is illustrated in Fig. 11.The degree of saturation for Jordan intersection is $0.996 \mathrm{v} / \mathrm{c}$

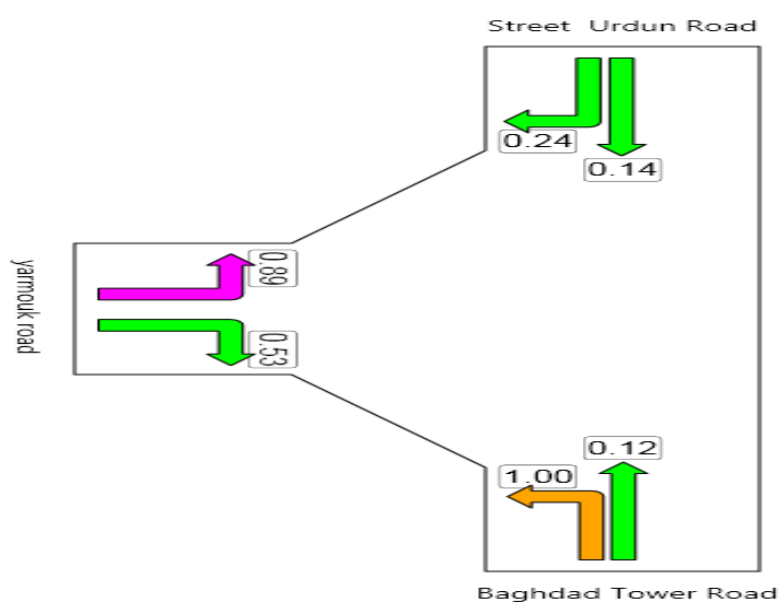


Fig.10. Results for degree of Saturation for Jordan intersection approaches

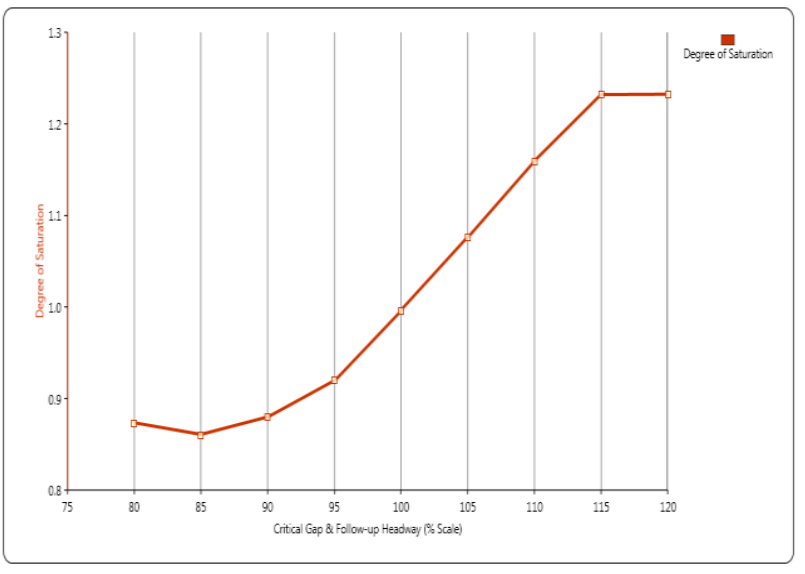

Fig.11. Relation between Degree of Saturation and follow up headway

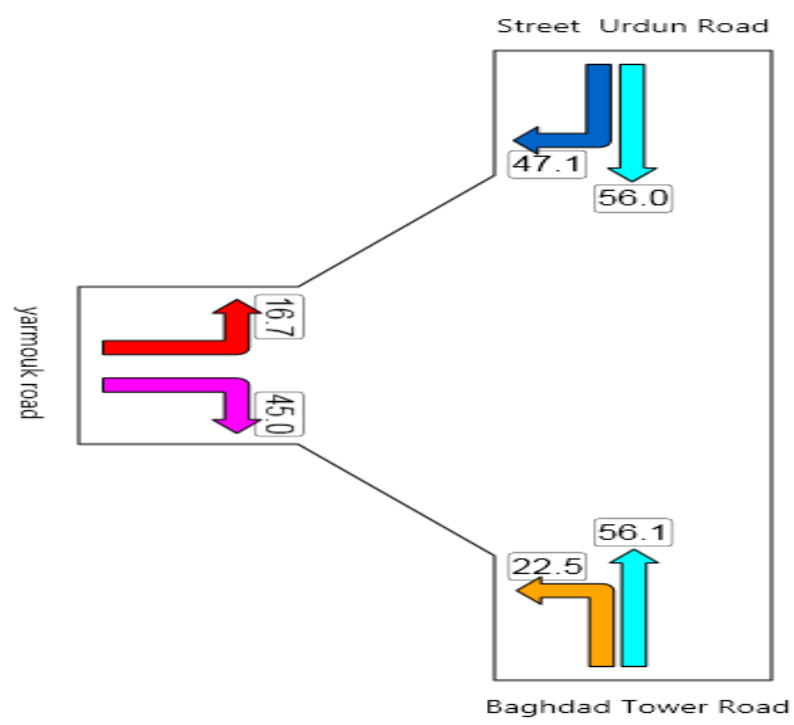

Fig.12. Results for Travel Speed for Jordan intersection approaches

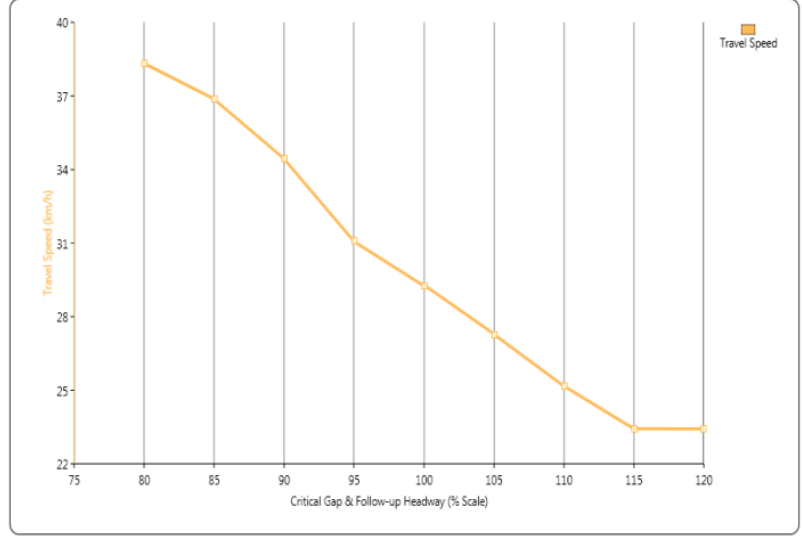

Fig.13. Relation between travel speed and follow up headway

\subsection{Travel speed}

Results for travel speed is indicated in Fig.12. According to colour code based on Speed Efficiency light blue colour and dark blue colour that the Speed Efficiency Ratio between (0.8-0.9) and (0.7-0.8).It was noted that Yarmouk Road has red colour and a pink colour which means the Speed Efficiency Ratio is between from (00.3 ) and (0.5-0.7) respectively. Whereas, Baghdad Tower road has a yellow colour and Light blue colour which means that the Speed Efficiency Ratio is between (0.3-0.5) and (0.8-0.9) as shown in Fig.12. A relation between travel speed and follow up headway is illustrated in Fig.13. It is significant to observe that the travel speed is adversely correlated with follow up headway when the travel speed increases the follow-up headway decreases. Travel speed for Jordan intersection is $29.3 \mathrm{~km} / \mathrm{h} \mathrm{sec}$.

\section{Conclusions}

Conclusions based on the investigation done in this study are below:

- The peak hour at Jordan intersection was recorded at 8:00 am with (4023 pc/h).

- The average delay is adversely correlated with LOS. Total delay for Jordan intersection was recorded as 36 sec; hence LOS of Jordan intersection is D.

- The degree of Saturation increases with follow up headway. The degree of saturation for Jordan intersection is 0.996 .

- Travel speed is adversely correlated with follow up headway. Travel speed for Jordan intersection is 29.3 $\mathrm{km} / \mathrm{h} \mathrm{sec}$ 


\section{References}

1. A. A. Mohammed, A.A. Shakir, Journal of Engineering Science and Technology. 8, 351-363 (2013)

2. A. A. Mohammed, Eng. \& Tech. 31, 774-792 (2013)

3. D. A. Al-Mimany, Eng. \& Tech. 5, 542-549 (2015)

4. N. J. Garber, L.A. Hoel, Traffic and Highway Engineering, Thomas Learning, Fourth Edition, (2010)

5. H. A. Awad, H.A. Mohammed, Anbar Journal for Engineering, 2, 3, 46-57 (2010)

6. M. R. Mahmoud, M.Sc. thesis, University of Technology, (2015)

7. M. A. bojaradwh, M. Msallam, B. Jew, Jour. of Environment \& Earth Science. 4, 12, 156-169 (2013)

8. D. Y. Karim, M.R. Mohamad, S. Abdullah. the Eastern Asia Society for Transportation Studies. 5, 5, 945-958 (2005)

9. A. A. Mohammed, Tikrit Jou of Eng Sciences, 20, 10-25 (2013)

10. R. Akcelik, SIDRA User Guide.Akcelik and Associates Pty Ltd, Melbourne, Australia. 341$347,2010)$

11. HCM Highway Capacity Manual, Transportation Research Board's (TRB) fifth edition of the Highway Capacity Manual HCM, Washington D.C. USA. 2-10 (2010)

12. B. H. Al-Omari ,M.M.Taamneh. Jordan Jour of Civil Engineering, 4, 375-392 (2007) 